\title{
ENSINO PROFISSIONALIZANTE EM GOIÁS: A EXPERIÊNCIA PIONEIRA DA COLÔNIA BLASIANA*
}

Joel Orlando Bevilaqua Marin**

\section{RESUMO}

No final do século XIX, o governo da Província de Goiás criou a primeira instituição de ensino profissionalizante, dirigida especialmente para crianças negras, pobres e abandonadas. A Colônia Blasiana foi concebida para formar trabalhadores para agricultura, fundamentando-se nos princípios educativos do trabalho e da disciplina. Reservava-se-lhes, porém, um espaço subalterno na divisão social do trabalho, pois, assim que se emancipavam, só restava aos "colonos" a possibilidade de se engajarem em serviços braçais nas fazendas particulares.

Palavras-chave: educação profissional; infância; ensino agrícola; Goiás.

Este artigo faz parte de um estudo mais amplo, em que se destacam os projetos de sociabilidade das novas gerações de trabalhadores no Estado de Goiás (MARIN, 2005). O foco da análise está centrado na Colônia Blasiana - instituição que pode ser considerada pioneira no ensino profissionalizante agrícola de Goiás - e, em especial, nas concepções e práticas do seu projeto educativo. Para tanto, recorreu-se ao estudo de diversos documentos redigidos na época, tais como relatórios oficiais do diretor e inspetores da Colônia, dos presidentes da Província de Goiás e de pesquisadores viajantes.

A Colônia Blasiana estabeleceu-se, no município de Santa Luzia, no dia 21 de abril de 1881, e permaneceu em atividade até o ano de 1895. Durante os catorze anos de existência, 43 meninos foram admitidos nessa escola cujo principal objetivo era proporcionar uma profissão nas áreas

\footnotetext{
* Artigo recebido em 16/3/2006 e aprovado em 25/5/2006.

** Professor da Universidade Federal de Goiás. E-mail: marin@agro.ufg.br
} 
do conhecimento da agricultura e da pecuária. Os alunos, genericamente denominados "colonos", eram "crianças desvalidas", filhas de escravos e de trabalhadores pobres

A Blasiana inspirava-se nas colônias orfanológicas criadas na Escócia e adotadas pela França, Inglaterra e por outros países europeus. Em termos legais, a Colônia Blasiana tinha fundamentação no artigo $2^{\circ}$ da Lei do Ventre Livre, que facultava ao Estado o poder de encaminhar para instituições credenciadas os filhos de escravas cedidos ao poder público, bem como os excessivamente castigados ou abandonados pelos seus senhores. Essas instituições tinham o direito de usufruir do trabalho das crianças até que elas completassem 21 anos de idade. Em compensação, cabia-lhes educar e tratar das crianças, além de formar um pecúlio e proporcionar uma colocação aos egressos. Essas instituições eram passíveis de inspeção por um juiz de órfãos, encarregado de averiguar as condições de funcionamento. $\mathrm{O}$ governo salvaguardava $\mathrm{O}$ direito de recolher as crianças filhas de escravas aos estabelecimentos públicos, quando essas instituições não cumprissem suas funções.

\section{QUESTÕES E DEBATES SOBRE O ENSINO AGRÍCOLA EM GoIÁS}

A criação da Colônia Blasiana deve ser entendida no contexto dos problemas sociais desencadeados no Brasil e em Goiás a partir da segunda metade do século XIX. Para efeitos desta pesquisa, três aspectos merecem destaque: (1) o Brasil e a Província de Goiás tinham suas economias estruturadas em um modelo agroexportador; (2) as relações de trabalho transformavam-se em decorrência da passagem do trabalho escravo para o livre; e (3) a infância pobre tornava-se objeto de preocupação por parte do Estado.

No final do século XIX, a economia brasileira sustentava-se na produção e exportação de produtos de origem agrícola. O aumento da produção agropecuária, que implicava o incremento das exportações, fazia-se basicamente pela incorporação de novas terras e de trabalhadores no processo produtivo. Contudo, nesse afã do aumento da produção, um fato não pode ser relegado: a necessidade de melhoria das práticas agrícolas utilizadas, o que tornava premente a criação de instituições de pesquisa e experimentação para proporcionar conhecimentos e tecnologias passíveis de emprego no aprimoramento da produção agropecuária. Nesse contexto, as elites dirigentes passaram a se interessar pela expansão de 
universidades, escolas agrícolas, estações experimentais, laboratórios de análises agropecuárias, bem como de colônias agrícolas.

No processo de expansão das atividades produtivas agropecuárias da Província de Goiás, os fazendeiros se deparavam com a falta de trabalhadores escravos, em decorrência da adoção de medidas restritivas ao tráfico negreiro e, posteriormente, da promulgação de diversas leis de libertação dos escravos (MARIN, 2004). Além disso, o momento de estagnação econômica vivido pela Província de Goiás tinha favorecido a venda de escravos para as regiões de maior dinamismo econômico, deixando, com isso, deficitário o quantitativo de mão-de-obra para as atividades produtivas. Enquanto os dirigentes das regiões Sul e Sudeste do Brasil estimulavam a política de imigração estrangeira para suprir a mão-de-obra necessária à agricultura, o governo da Província de Goiás afirmava que não tinha recursos suficientes para subvencionar a imigração de trabalhadores estrangeiros e que nem mesmo os imigrantes demonstravam interesse em trabalhar em uma região pobre e distante do litoral.

Para solucionar esse problema da escassez de braços para a agricultura, o governo da Província de Goiás investiu grandes somas de recursos financeiros na política indigenista, que se resumia a projetos de "civilização" dos índios. No intuito de formar trabalhadores nacionais, esses projetos se assentavam, de maneira especial, na construção de presídios militares ao longo dos rios Araguaia e Tocantins (RocHA, 1998), no incentivo à catequese ministrada pelos padres capuchinhos $\mathrm{e}$ dominicanos (Rocha, 1998; SANTOS, 1996), no rapto de crianças indígenas e na criação do Colégio Isabel (MARIN, 2005).

Para aumentar o quantitativo de mão-de-obra, o governo também elaborou dispositivos legais para disciplinar a massa de trabalhadores e reprimir a vagabundagem. O processo progressivo de libertação dos escravos, por um lado, aumentava o número de pobres e marginalizados, que perambulavam pelas cidades, vilas ou campos e passavam a ser percebidos como uma ameaça à ordem social instituída. Por outro lado, o fim da escravidão implicava a falta de mão-de-obra e colocava as atividades produtivas agropecuárias em risco de colapso, tornando necessário preparar trabalhadores para as mudanças em curso.

Em meio a essas mudanças nas relações sociais de trabalho e de crescimento da população marginalizada surgiram os primeiros projetos de formação das futuras gerações de trabalhadores. A promulgação da 
Lei do Ventre Livre, no ano de 1871, trouxe à tona o debate da problemática da "infância desvalida" e exigiu do Estado a proposição de políticas dirigidas especificamente para as crianças. Essa lei impôs à sociedade brasileira uma nova percepção da infância, pois o destino da vida das crianças, que era traçado no âmbito restrito das famílias de seus donos, tornou-se questão de responsabilidade do poder público. A partir daí, ampliaram-se as atribuições do Estado com a criação e educação das crianças, especialmente daquelas que se encontravam na pobreza, no abandono e em risco de sucumbir à marginalidade (RizzINI, 1995; FALEIROS, E. T. S., 1995; Faleiros, V. P., 1995).

O governo da Província de Goiás, historicamente, demonstrava pouco interesse pela educação escolar da população infanto-juvenil: não repassava recursos financeiros suficientes; o número de escolas era reduzido; os baixos salários desestimulavam os professores, o que resultava no fechamento de muitas escolas; as salas de aulas funcionavam em locais improvisados, sem muito asseio e precariamente munidas de móveis e de materiais didáticos; os livros impressos existentes restringiamse a alguns compêndios da doutrina cristã e da gramática da língua portuguesa. Para os alunos pobres, as dificuldades eram ainda maiores, em razão da falta absoluta dos materiais mais elementares para o aprendizado (BRETAS, 1991).

No ano de 1862, em toda a Província de Goiás, havia 65 escolas públicas primárias, sendo 42 para o sexo masculino e 23 para o feminino. Todavia, apenas 42 estavam em funcionamento: dez escolas para o sexo masculino e treze para o sexo feminino encontravam-se com suas portas fechadas. Isto significa que mais de $35 \%$ das instituições de ensino primário estavam paralisadas, mormente aquelas voltadas para educação das meninas. ${ }^{1}$

Por esses motivos, poucos alunos conseguiam freqüentar a escola. Um relatório da presidência da Província de Goiás, datado em 1869, estimava que a população livre de Goiás era de 150 mil pessoas, sendo que 5\% estavam em idade escolar, o que corresponderia a aproximadamente 7.500 crianças. Todavia, os dados oficiais sobre a instrução pública indicavam que somente 1.153 crianças freqüentavam a escola, o que representava apenas $15 \%$ da população em idade escolar. ${ }^{2}$

$\mathrm{O}$ quadro era mais sombrio quando os alunos eram filhos dos agricultores pobres. Estes ficavam afastados das escolas porque tinham necessidade de trabalhar para garantir a sobrevivência. Para os pobres, 
o sertão era a escola. Para viver e sobreviver no sertão, acreditava-se que bastaria apenas o aprendizado das lidas da casa, da lavoura ou das criações. Para o homem do campo, ler, escrever e contar, as atividades propugnadas pela escola, tinham pouquíssima importância se comparadas aos conhecimentos práticos atinentes ao amanho da terra, aos tratos das plantas e dos animais, bem como aos cuidados do lar - estes sim eram considerados imprescindíveis ao estilo de vida do homem simples do campo, enquanto os adquiridos na escola tinham pouca aplicabilidade no cotidiano. Ao deixar de associar convenientemente os dois tipos de conhecimentos, a escola distanciava-se dos problemas sociais imediatos da população e afastava-se do círculo de compreensão dos pais das crianças.

Nos sucessivos relatórios, os presidentes da Província atribuíam aos pais a culpa pela não-escolarização dos filhos. Porém, o presidente Francisco Januário da Gama Cerqueira registrou, em um relatório, que a população goiana desejava que seus filhos freqüentassem a escola, a fim de que vida deles não fosse a mesma das gerações adultas: "Releva aqui notar que tenho observado que nossos homens do campo, ainda os mais ignorantes, lamentão que seus filhos fiquem, como elles, sem saber ler e escrever, por falta de meios". 3

Nesse mesmo relatório de 1858, surgiu o primeiro registro documental da proposta de criação de escolas para transmitir conhecimentos na área agrícola para as crianças. $\mathrm{O}$ presidente Francisco Januário recomendava a fundação de escolas em sistema de internato para receber meninos pobres, alfabetizá-los e profissionalizá-los nas lidas agropecuárias. Além de solucionar o problema da evasão escolar, essas escolas poderiam contribuir para as mudanças das práticas rotineiras dos agricultores, mediante a introdução de novos conhecimentos:

As casas dos internatos poderião ter grandes chacaras e quintaes, aonde os meninos poderião se empregar em trabalhos proprios de suas idades, recebendo ao mesmo tempo algumas licções praticas de agricultura, que os habilitassem, ao menos, a julgar da possibilidade de deixar-se o systhema rotineiro, exclusivamente seguido por todos os nossos lavradores.

Essa proposta esbarrava, no entanto, na falta de recursos para construir e manter um estabelecimento dessa magnitude. Algumas décadas depois, o governo imperial - através do Ministério dos Negócios 
da Agricultura, Comércio e Obras Públicas ${ }^{-}$recomendou a criação de escolas agrícolas na Província goiana, para que as novas gerações pudessem acompanhar o progresso do país:

O ministerio da agricultura ponderando-me a conveniencia de, n'um paiz essencialmente agricola, como é o Brasil, preparar se a mocidade com estudos elementares sobre tudo que entende com a cultura do sólo e serviços da lavoura, recomendou-me que nesta provincia, indicando os meios de que devia lançar mão e declarando-me que o governo imperial terá como serviço relevante e digno de maior apreço o que for prestado para a realisação dessa idéia, que tanto deve contribuir para a prosperidade nacional. ${ }^{4}$

Em cumprimento a essa ordem ministerial, o presidente da Província dirigiu-se aos representantes dos municípios para que indicassem cinco "membros idôneos e influentes" para promover a criação das escolas agrícolas. Alguns municípios, como Goiás (capital), Meia Ponte, Santa Cruz, Entre-Rios, Catalão, Pilar, São José do Tocantins, Cavalcante, Forte, São Domingos, Conceição, Natividade, Palma e Morrinhos, criaram comissões para discutir a questão, mas as escolas agrícolas não chegaram a se concretizar. As razões da não-implementação dessa proposta podem ser atribuídas à falta de recursos financeiros e, sobretudo, ao interesse e despreparo das pessoas para conceber e gerir instituições daquela envergadura.

A criação da primeira instituição orientada para o ensino profissionalizante agrícola ocorreu no ano de 1881, graças ao empenho pessoal de Joseph de Mello Alvares, que foi diretor da Colônia Blasiana desde a fundação até a extinção. Mello Alvares era um homem culto, defensor da abolição da escravatura e dos ideais positivistas. Político ativo, foi vereador por seis legislaturas em Santa Luzia, intendente municipal por dois mandatos e deputado provincial por duas vezes consecutivas. Atuou na área de saúde, como médico e farmacêutico prático; como advogado, exerceu o cargo de juiz de paz. Na área de educação, foi delegado literário do município de Santa Luzia. Interessado pela vida cultural de seu município, publicou um livro intitulado Descrição histórica, política e geográfica de Santa Luzia. Filiou-se a várias associações científicas nacionais e internacionais, com as quais manteve um intenso intercâmbio, que lhe rendeu viagens e doações de recursos financeiros, livros, revistas e jornais. Na área agrícola, defendeu a modernização das técnicas 
agropecuárias e desenvolveu vários experimentos e inovações na Colônia Blasiana. $^{5}$

Espelhando-se no modelo de desenvolvimento rural da França, Mello Alvares defendia a propagação, em todos os recantos do Brasil, de escolas agrícolas, estações experimentais e institutos de análises laboratoriais agrícolas, para promover o progresso técnico e difundir conhecimentos científicos e inovações tecnológicas advindos do avanço da ciência. Teorizava também que essas instituições poderiam proporcionar técnicas e conhecimentos científicos aos agricultores, capacitandoos, assim, para as mudanças das práticas rotineiras então utilizadas:

As estações agronomicas concorrerão forçosamente para fazer o paiz entrar cheio de força e vigor na larga estrada que lhe está traçado pelos sorprehendentes progressos da agronomia moderna. O que não é possivel é manter o status quo ou pretender debellar a crise por uma serie de expedientes que por mais bem combinados que sejam, não podem constituir uma verdadeira solução. É preciso tratar da organização do ensino agricola no Brasil, crear estações agronomicas e laboratorios de analyses agricolas, seguir em uma palavra, a experiencia dos paizes cultos. Exemplos e modelos não faltam, e o essencial é saber adoptal-os as nossas condições. [...]. O aproveitamento dos dados científicos, principalmente das sciencias biologicas, a utilização do methodo experimental, constitui uma necessidade de primeira ordem, para o grande como para o pequeno proprietário, para o simples lavrador, como para o chefe de uma grande exploração agricola. $^{6}$

Em relação às escolas técnicas, Mello Alvares defendia, no mesmo relatório, a tese de que o governo deveria investir na expansão do ensino profissional, não apenas para promover o desenvolvimento tecnológico nas atividades agropecuárias, mas também para criar oportunidades para as novas gerações. As escolas profissionalizantes em agricultura poderiam, assim, aproximar os jovens dos conhecimentos científicos, desenvolvendo neles a inteligência e o amor ao trabalho. Segundo ele, o objetivo cumprido resultaria na prosperidade individual e nacional:

A deficiência em que está no Brasil o ensino profissional da agricultura, exige alta e poderosamente escolas agrícolas, onde a mocidade possa aperfeiçoar-se e concorrêr pela intelligencia e pelo trabalho, para a prosperidade nacional. 
Além de abrir novas oportunidades de trabalho, as escolas agrícolas cumpririam o importante papel de disciplinar as novas gerações, afastandoas do abandono e da marginalidade. O diretor da Colônia Blasiana estimava que só na Província de Goiás havia uma população de "vinte cinco mil orphans filhos do pauperismo". Se educados no trabalho, eles se iriam se tornar úteis a si mesmos e à nação. Por essa razão, ele alertava, ainda no mesmo relatório, para o fato de que a proliferação das colônias orfanológicas poderia tornar-se uma poderosa medida de salvação dos "ingenuos e orphans que as centenas vagam desamparadas, que se não morrerem a mingua de alimentos, se constituirão malfeitores".

Na visão do diretor da Colônia, cabia ao Estado a obra humanitária de ser "o primeiro protector da nobilissima causa da educação profissional do povo". Para isso, era seu dever criar e manter as instituições sociais para encaminhar as crianças pobres e abandonadas. ${ }^{7}$ Em um de seus relatórios, Mello Alvares clamou ao presidente da Província:

Do alto da posição em que V. Exma. se acha collocado, desça suas vistas humanitarias e progressistas sobre tantos innocentes filhos do povo que no alto sertão do Brasil que se perdem porque não tem quem lhes dirija no caminho da vida social, que se desgração por falta do pão do espirito e do corpo. ${ }^{8}$

Sob o amparo da legislação vigente no país e ciente da importância das instituições públicas no desenvolvimento tecnológico e humano, bem como no papel moralizador do trabalho, Alvares Mello criou e dirigiu a Colônia Blasiana, estabelecida no município de Santa Luzia, atual Luziania.

\section{Diretrizes PEDAGÓGICAS E ADMINISTRATIVAS da ColôNia Blasiana}

Os processos de controle e disciplinarização da sociedade assumiram dimensão internacional. Na Europa, como destacou Foucault (1986), a emergência do capitalismo industrial ampliou a preocupação com a disciplinarização da sociedade. As elites dominantes passaram então a se preocupar não apenas com as infrações cometidas pelo sujeito, mas também com aquelas que poderiam vir a cometer. $\mathrm{Na}$ "sociedade disciplinar", o controle social recaía sobre o que o indivíduo era e também o que poderia vir a ser, ou seja, sobre as suas virtualidades.

No Brasil, país marcado por uma herança de mais de três séculos de escravidão, o controle sobre as virtualidades dos indivíduos, 
especialmente os pobres e os negros, também assumiu a dimensão de problema social; resultando daí o surgimento de aparatos legais e de instituições públicas de enfrentamento. Como destacaram Coimbra \& Nascimento (2003), algumas teorias que emergiram na Europa no século $\mathrm{XIX}$, como as racistas e as eugênicas, tiveram reflexo no Brasil e contribuíram significativamente para constituição das nossas subjetividades sobre pobreza e periculosidade. Tais teorias condenavam as misturas raciais e as caracterizavam como indesejáveis e produtoras de enfermidades e de doenças físicas e morais. O Tratado das degenerecências, de Morel, e As origens das espécies, de Darwin, influenciaram os meios científicos da medicina, do direito, da arquitetura, da educação e da antropologia, atraindo diversos intelectuais brasileiros:

Esta elite científica estava convencida de sua "missão patriótica" na construção de uma "nação moderna". Suas propostas pautavam-se por medidas que deveriam promover o "saneamento moral" do país. A "degeneração moral" era especialmente associada à pobreza e percebida como epidemia que se deveria evitar. Para erigir uma nação, os higienistas afirmavam que toda a sociedade deveria participar dessa "cruzada saneadora e civilizatória" contra o mal que se alojava no seio da pobreza. Esse movimento imiscuiu-se nos mais diferentes setores da sociedade, redefinindo os papéis que deveriam desempenhar em um regime capitalista a família, a mulher, a cidade, as elites e os segmentos pobres. (CoImBra; NASCimento, 2003, p. 23-24)

O capitalismo liberal precisava de trabalhadores livres para oferecer e vender a sua força de trabalho, mas estes deveriam ser mantidos sob controle em seus devidos lugares, respeitando a divisão social de classe. Sob a ótica do capital, o trabalho tornou-se o meio por excelência para alcançar o progresso individual e social, enquanto a miséria passou a ser naturalmente associada à ociosidade, à indolência e aos vícios da população pobre.

Com o propósito de formar trabalhadores disciplinados, criaramse instituições públicas dirigidas às novas gerações, pois elas representavam o futuro do novo país que se pretendia construir, a partir de então, livre da escravatura. A Colônia Blasiana surgiu, na Província de Goiás, na condição de instituição pública comprometida com a educação profissional daquelas crianças que representavam perigos potenciais para a sociedade. 
As diretrizes pedagógicas e administrativas da instituição foram estabelecidas pelo Regulamento da Colônia Blasiana, documento disposto em seis capítulos: I - Da instituição orphanologica, II - Da admissão dos colonos, III - Dos direitos e deveres dos colonos, IV - Do diretor, V - Do juiz de órphãos, VI - Disposições gerais. ${ }^{9}$

O primeiro capítulo do Regulamento definia a Colônia Blasiana como "um estabelecimento agricola e industrial, sugerido pelo pensamento humanitario e civilizador, de tornar uteis a si e a pátria os orphans desvalidos do municipio de Santa Luzia". A instituição tinha como objetivos: 1) promover a instrução e a habilitação profissional dos colonos, 2) desenvolver o gosto pelos conhecimentos agrícolas e industriais disponíveis na época, 3) proporcionar trabalho e remuneração correspondente, a fim de que as crianças pudessem formar um pecúlio para começar a vida depois de deixar o estabelecimento ou auxiliar os familiares em casos de doença grave ou extrema penúria.

Na Colônia Blasiana eram admitidos "órfãos desvalidos", com idade de sete anos completos, que permaneciam até os 21 anos, quando então atingiam a maioridade. Os colonos poderiam se afastar da instituição só por consentimento do diretor ou do juiz de órfãos. O Regulamento determinava que o estabelecimento poderia receber um máximo de quarenta colonos e um mínimo de quinze. Se existisse algum órfão no município, o diretor da Colônia podia requer sua admissão, através de um ofício dirigido ao juiz de órfãos.

Quanto aos direitos e deveres dos colonos, o terceiro capítulo do Regulamento definia que, ao ingressar na Colônia, as crianças deveriam receber um número de identificação, pelo qual seriam chamados. Com esse número, marcavam-se seus objetos de uso pessoal. Cada aluno também recebia um conjunto de roupas de algodão para o trabalho e para as demais atividades da instituição. Para os dias festivos, os meninos vestiam um uniforme numerado, composto de calça branca, blusa de brim pardo, com debrum nos punhos e as letras "C.B." ao lado esquerdo do peito, boné azul e um par de sapatos de couro.

Os alunos tinham direito de receber, do diretor ou de pessoas habilitadas, instrução primária, conhecimentos agrícolas e industriais e fundamentos da doutrina cristã. Ao final de cada ano, os colonos recebiam um salário estipulado pelo juiz de órfãos, em acordo com o diretor. Esse salário deveria aumentar progressivamente a cada biênio. Porém, o artigo 13 do Regulamento da Colônia Blasiana admitia: "no fim de cada ano 
recolhera o juiz de orphans a importancia dos salarios de cada colono para ser dada por emprestimo ao Estado, o que não o fazendo serão considerados desfeitos os contractos perdendo o direito ao colono".

Os meninos deviam obedecer ao diretor e aos demais funcionários, mostrando-se sempre atentos aos seus conselhos e às suas advertências. Aqueles que cometiam atos considerados irregulares estavam sujeitos às penalidades determinadas pelo diretor, como, por exemplo, repreensão na presença dos colegas e prisão de um a oito dias, com redução da metade da alimentação.

De acordo com o quarto capítulo, cabia ao diretor as seguintes atribuições: cumprir e fazer cumprir as disposições do Regulamento; ministrar ou fazer ministrar o ensino aos alunos; dar alimentação, vestuário e medicamentos aos alunos; estabelecer um regime interno para organizar o tempo para as aulas, alimentação e trabalho dos colonos; fazer com que os colonos participassem das festividades cívicas e religiosas; e administrar os recursos financeiros da instituição.

O juiz de órfãos era o "protector nato da Colônia", cabendo-lhe zelar pela ordem, moralidade e estabilidade da instituição; celebrar, com o diretor, todos os contratos referentes à instituição; abrir, rubricar e numerar o livro da Colônia; distribuir prêmios aos colonos; visitar mensalmente a Colônia; e mediar os conflitos entre alunos, diretor e professores.

As disposições gerais do Regulamento da Colônia Blasiana estabeleciam que os colonos de bom comportamento podiam visitar periodicamente seus parentes e que, no dia vinte de dezembro de cada ano, o juiz de órfãos, o diretor e autoridades convidadas deviam entregar prêmios aos colonos que se destacavam pela sua moralidade, aplicação e pelo seu aproveitamento. Nos casos de moléstia contagiosa ou crônica, diagnosticada por um médico, o aluno receberia dispensa provisória ou definitiva.

Em suma, o propósito da Colônia Blasiana era educar as crianças, filhas de escravos, órfãs ou abandonadas, a fim de qualificá-las para o trabalho e torná-las úteis para o progresso econômico do país. Além de uma questão econômica, a preparação de trabalhadores mais qualificados profissionalmente assumia importância no combate à marginalidade, problema que se agravava com a libertação dos escravos. Através de uma instituição de amparo à "infância desvalida", o diretor da Colônia acreditava que, "em vez de parasitas larapios, e assassinos, [teria] cidadãos moralizados, importantes cooperadores do progresso do pais". ${ }^{10}$ 
Nesses termos, as elites dirigentes construíam um discurso ideológico, que se reproduz no senso comum até a atualidade, quando se admite naturalmente o trabalho desde tenra idade como meio privilegiado para contrapor-se aos riscos da marginalidade. Sob uma visão moralista, a socialização para o trabalho seria capaz de dignificar e transformar a existência das pessoas, de modo a orientá-las para a edificação do bem individual e social. Esse processo de preparação da mente e do corpo para o trabalho deveria começar nos primeiros anos de vida, pois a infância era considerada a fase da vida ideal para formar o caráter das pessoas. A educação fundamentada no rigor do trabalho e dos valores morais e cristãos era uma forma de encaminhar os "inocentes filhos do povo" e "desherdados da fortuna" e de construir uma nova civilização comprometida com o engrandecimento da pátria.

\section{As PRÁTICAS EDUCATIVAS DA COLÔNIA Blasiana}

A disciplina ordena os espaços, da mesma maneira que a organização racional dos espaços facilita o controle disciplinar. Como sustenta Foucault (1979, p. 106), "a disciplina é uma técnica de poder que implica uma vigilância perpétua e constante dos indivíduos". A disciplina deve ser estendida ao controle e à manipulação dos gestos e do corpo, para que os indivíduos introjetem as normas disciplinares. Nessas condições, "a disciplina fabrica corpos submissos e exercitados, corpos 'dóceis' " (Foucault, 1979, p. 127).

$\mathrm{Na}$ Colônia Blasiana, as crianças eram submetidas a uma vigilância constante de seus tempos e de suas atividades. Eram treinadas para executar as determinações da instituição, conforme os procedimentos por ela definidos. O trabalho e o castigo tornavam-se meios privilegiados do processo contínuo de disciplinarização do corpo, o que fazia com que as crianças internalizassem as normas determinadas pela instituição e se submetessem a elas. O processo educativo perpassava todos os espaços e momentos de vivência das crianças na instituição. Nas salas de aula, no trabalho, nos dias de descanso e nas festividades cívico-religiosas, os estudantes eram envolvidos em um contínuo processo de formação pessoal e profissional.

Implantada na Fazenda Conceição, na margem esquerda do Rio Corumbá, a dezoito quilômetros da cidade de Santa Luzia, a Colônia 
Blasiana dispunha de diversos prédios modestos que serviam para diversos fins. O principal, denominado Diretoria, era utilizado como moradia da família do Joseph de Mello Alvares e suas empregadas, como escritório, sala de aula e biblioteca da Colônia. Um outro, denominado Quartel, era a habitação das crianças e jovens estudantes da Colônia. Por último, os Armazéns eram compostos de três anexos: o primeiro era a moradia dos professores e demais funcionários, o segundo servia para guardar os instrumentos e produtos agrícolas, e o terceiro era utilizado como estábulo e pocilga para os animais domésticos. A frente desse conjunto de edificações era protegida por uma muralha de pedras; os fundos, por um tributário do Rio Corumbá; e, nas laterais, por leiras de aroeira branca. Entre os prédios existiam praças cujos nomes homenageavam pessoas influentes no cenário político da época, tais como: D. Pedro II, Dona Isabel, Dona Teresa Cristina e Conselheiro Moreira Pessoa. Nesses locais, cultivavam-se hortaliças e árvores frutíferas e mantinha-se um pátio de secagem dos produtos agrícolas. As construções foram projetadas para receber iluminação solar e ventilação e, regularmente, eram varridas e lavadas, para garantir asseio e evitar enfermidades.

Durante seus catorze anos de existência, a Colônia Blasiana funcionou com um número médio de 25 crianças; o maior número foi 36 , no ano de 1884 , e o menor número, 17 , nos últimos três anos de funcionamento. Os meninos internos da instituição educativa eram filhos de escravas e órfãos "distribuidos pelos particulares sem vencerem salario algum, vivendo na maior penuria e recebendo o pior tratamento em uma especie de cativeiro. Todos desvalidos viviam na miséria em poder de pessoas estranhas sem autorização legal". ${ }^{11} \mathrm{O}$ diretor afirmava que não gostava de receber "menores" com mais de doze anos de idade porque "eram muito viciados".

A escola da Colônia, denominada dr. Gusmão Lobo, estruturava seu projeto pedagógico em três áreas, denominadas "aulas". Os conteúdos da "aula Tristão Brandão" eram a leitura, a escrita, as operações fundamentais da aritmética e a doutrina cristã. Na "aula João Gonzaga", os meninos recebiam noções de música, leitura de partituras, exercícios vocais e de respiração, cantos religiosos e patrióticos, coro uníssono, a duas e a três vozes. Na "aula Visconde do Bom Retiro" eram ministrados ensinamentos de agricultura prática, tais como: uso dos instrumentos agrícolas, preparo do solo para plantio, tratos culturais desde germinação até o completo crescimento, colheita dos produtos, armazenagem e 
processamento dos produtos agrícolas, estudos sobre adubos orgânicos, tratamento dos animais domésticos e seu melhoramento, cultivos e tratos das hortaliças, enxertia e práticas de jardinagem.

A importância e o tempo de cada uma das "aulas" eram diferenciados. Os ensinamentos da leitura, da escrita e das operações matemáticas eram ministrados nos primeiros anos após o ingresso na Colônia. Assimilados esses conteúdos, os alunos passavam progressivamente para o aprendizado prático da agricultura e pecuária. Contudo, um funcionário do governo constatou que nem todos os alunos aprenderam a ler, a escrever e a contar satisfatoriamente. ${ }^{12}$

A iniciativa de ensinar canto e música aos colonos não teve êxito. O diretor da Colônia afirmava que o ensino de canto e música visava:

dulcificar os costumes das creanças procedentes de pessoas que se não são parecem ser selvagens, para com mais facilidade gravar no espírito d'ellas o conhecimento dos seus direitos e dos seus deveres, e assim animal-as a receber a educação que lhes está destinada. ${ }^{13}$

Ressaltava o talento musical nato de alguns alunos e, constantemente, solicitava ao governo provincial verbas para adquirir instrumentos musicais para formar uma banda. Esses pedidos, porém, não eram atendidos. O governo da Província de Goiás ora alegava que lhe faltavam recursos financeiros para esse tipo de projeto ora culpava o diretor da Colônia pela não-apresentação de relatórios completos das atividades e das despesas realizadas na instituição. Em 1889, o professor de música afastou-se por motivos de saúde; sem professor, nem instrumentos musicais, a "aula João Gonzaga" acabou suprimida.

Os ensinamentos voltados para agricultura e pecuária adquiriram, então, maior importância na instituição e ocupavam a maior parte do tempo das crianças. No desenvolvimento das atividades agropecuárias, aproveitava-se regularmente da força de trabalho dos colonos, especialmente daqueles que tinham maior vigor físico e com mais de doze anos de idade. A metodologia de ensino agrícola estava fundamentada na experimentação e na observação direta dos alunos, proporcionada no cotidiano da instituição, que funcionava em sistema de internato.

Na Fazenda Conceição, criavam-se bovinos, eqüinos, caprinos, ovinos, suínos e aves, de raças consideradas superiores, a fim de melhorar o plantel da fazenda e das propriedades da região. Para conseguir os 
animais geneticamente melhorados, o diretor da Colônia estabelecia diversos contatos com as instituições científicas existentes na época e com criadores experientes. O manejo dos animais domésticos estava integrado às atividades agrícolas através do uso da tração animal, do aproveitamento do estrume para adubação orgânica e dos restos cultivares para alimentação do gado nos estábulos.

As plantações eram divididas em vinte talhões, separados por largas leiras de plantas frutíferas ou ornamentais, que serviam de quebra-vento, barreira de retenção das águas fluviais e prevenção da erosão. Nos talhões, cultivavam-se cerca de quarenta produtos agrícolas de consumo do pessoal da fazenda e do rebanho, além de plantas medicinais. Dentre os cultivos destacavam-se: café, feijão, arroz, milho, trigo, mandioca, canade-açúcar, batata doce, batata inglesa, cará, inhame, gengibre, amendoim, gergelim, erva-doce, algodão, tabaco, fava, linho, centeio, cevada, trevo, sorgo, guandu, urucum, anil, lúpulo, palmeiras, marmelo, videiras, bananeiras, chá. Algumas espécimes exóticas ao cerrado foram introduzidas em Goiás através da Colônia Blasiana, como eucalipto, quina calysaia, além de diversas variedades de cana-de-açúcar, café, pimenta, trigo, canela, cravo, baunilha e videiras. O desenvolvimento das plantações e criações tinha como preceito a conjunção dos dados científicos, com a utilização dos métodos experimentais.

É importante observar que os preceitos do desenvolvimento agrícola adotados na fazenda da Colônia Blasiana estavam em consonância com a revolução agrícola que estava se processando na Europa (VEIGA, 1991). Os conhecimentos científicos eram apropriados através das visitas do diretor às instituições científicas existentes no Brasil e, de maneira especial, através dos livros. Na Colônia havia uma biblioteca, denominada Senador Corrêa, com um acervo de vários periódicos e livros de edições nacionais e estrangeiras, muitos deles doados, graças à influência do diretor nos meios científicos e políticos, tanto no cenário regional quanto nacional.

Além do trabalho, o prêmio e o castigo eram os princípios educativos empregados na Colônia Blasiana. A premiação - com a concessão de condecorações ou de objetos, como livros e instrumentos aperfeiçoados da lavoura e da indústria - visava distinguir e valorizar os alunos interessados em aplicar os ensinamentos repassados pela instituição. As admoestações, a redução da alimentação, os castigos físicos e a detenção da liberdade faziam parte de um repertório de práticas pedagogicamente 
utilizadas para corrigir os alunos transgressores e impor os limites da sociabilidade dentro da instituição. A premiação e o castigo eram feitos às vistas dos demais alunos, para que as honras ou as corrigendas se tornassem exemplares, estimulando ou inibindo determinados comportamentos. Mello Alvares, no relatório datado de 15 de junho de 1889, ressaltava, contudo, que o castigo deveria ser aplicado nas situações extremas:

Compreendendo que se o emprego dos meios rigorosos não está inteiramente abolido na educação do homem, não se deve com tudo recorrer a elles senão na ultima extremidade, que é dever do preceptor fazer o educando ouvir a vóz da razão e que a força, ultima ratio, so deve intervir quando elle torna-se surdo a linguagem da verdade, quando não mais escuta a exhortação do bem; tenho dirigido os colonos de modo que elles me tributam um amôr quase filial que eu aceito como galardão dos sacrificios de toda a sorte que por elles tenho feito.

Ainda para cultuar a disciplina na instituição, o diretor criou um espécie de tribunal infantil, com um "juizado" constituído de alunos para julgar os delitos cometidos na instituição, cabendo recursos e apelações às decisões. Assim, ao mesmo tempo, os alunos julgavam-se e vigiavamse para manter a moralidade dentro da escola. Outro objetivo, segundo o diretor, no mesmo relatório, era o de iniciar os alunos no "conhecimento d'essa instituição moral e philophica que se chama Jury".

A doutrina católica também fazia parte dos conteúdos da Colônia Blasiana, uma vez que o catolicismo era considerado a religião oficial do Estado. Por isso, o cotidiano dos alunos estava permeado pelos ensinamentos e rituais religiosos: eles rezavam e entoavam hinos no início das aulas e das tarefas agrícolas, no horário das refeições e antes de dormir. Nos domingos, a obrigação era assistir à missa e rezar a ladainha de Nossa Senhora. Nas festas religiosas do Natal, Semana Santa, Espírito Santo, Padroeira de Santa Luzia e outros santos católicos, os colonos participavam das celebrações, vestindo os trajes da Colônia.

Uma outra preocupação do diretor da Colônia era o de promover a saúde através da adoção de práticas da higiene pessoal e do asseio da moradia. Para ensinar os princípios higiênicos, o diretor dizia associar a palavra ao exemplo. Dessa forma, difundia entre os alunos conceitos e práticas bem distintos dos hábitos da maioria dos lavradores de Goiás, 
que desconheciam os cuidados higiênicos básicos e viviam em promiscuidade com os animais domésticos e seus detritos.

Assim, o trabalho e a disciplina assumiam o papel de salvação da infância abandonada e pobre. As novas gerações deveriam receber uma educação que as preparassem para os desafios do trabalho. Com base nesses pressupostos, o diretor acreditava que formaria pessoas dignas e morigeradas, capazes de trabalhar para o engrandecimento da pátria. Sob essa perspectiva, a Colônia Blasiana abria

um vasto campo ao exercício da caridade, perfilhando e mobilizando os inocentes, sem pai e sem nome, os engeitados sem crime, as vitimas da deshonra, os verdadeiros parias da sociedade, transformando-os em benemeritos cidadãos, esteios da pátria e brazões vivos do trabalho. ${ }^{14}$

Os governantes, embora reconhecessem a problemática da infância pobre e abandonada, não demonstravam muito interesse na manutenção financeira dos poucos estabelecimentos educativos. A falta de responsabilidade do governo com os programas sociais foi o fator que mais contribuiu para o aniquilamento da experiência implantada em Santa Luzia.

Em 1882, a Colônia recebia uma subvenção anual do governo da Província de Goiás no valor $5.000 \$ 000$ réis, passando para $6.000 \$ 000$ réis no ano de 1884. Em razão de considerar o montante irrisório, Mello Alvares apresentava um orçamento em que detalhava os gastos anuais com alimentação, vestuário e educação. Para isso precisava-se da importância de $9.576 \$ 000$ réis. O diretor constantemente afirmava, reiterado por outras pessoas, que tirava dinheiro do próprio bolso, para garantir a manutenção da instituição.

Todavia, entre pessoas físicas, jurídicas e agentes religiosos, havia cerca de trinta doadores que contribuíam para o orçamento da Colônia, através de donativos em dinheiro, em livros e periódicos, para ampliar o acervo da biblioteca, ou através da doação de animais melhorados, sementes e mudas de plantas. ${ }^{15}$ Ademais, na fazenda da Colônia, produziase grande quantidade de alimentos, oriundos das plantações e criações, que supriam, senão totalmente, pelo menos grande parte da alimentação dos meninos.

Num relatório de 15 de março de 1884, o diretor avaliava que os resultados do aprendizado dos trabalhos nas lavouras e criações da Fazenda Conceição eram muito positivos: 
Todos os alumnos d'esta aula já sabem applicar a charúa, a grade e outros instrumentos, empregar os necessários agentes fertilisadores, plantar e cultivar, já tratam dos animais domésticos e comprehendem o modo de seu melhoramento, são bons horticultores e jardineiros.

Políticos, missionários, pesquisadores e viajantes que passaram na Colônia fizeram calorosos elogios à organização da fazenda, aos experimentos, às plantações, às árvores frutíferas e ornamentais, às hortaliças, bem como à criação do gado. A racionalização dos espaços, a experimentação, o melhoramento genético dos animais, bem como a difusão de plantas exóticas e de novas variedades de cultivares certamente encantavam todos os visitantes, em razão do visível contraste com a maioria das fazendas goianas, mergulhadas no atraso, utilizando práticas e técnicas rotineiras, onde o improviso e a falta de asseio reinavam absolutos. Oscar Leal (1980, p. 142), nos registros de sua viagem a Goiás, teceu comentários lisonjeiros sobre a instituição e o trabalho do diretor:

Não só o asseio, a simetria na disposição das plantas, a ordem e boas maneiras dos órfãos, que nos elevaram, juntemos a isto a amabilidade e boa vontade do diretor e de sua família para com os hóspedes. Esta colônia tem sido visitada por vários homens notáveis que tem governado Goiás, e todos creio, admiram a atividade e proficiência com que dirige a mesma o ilustrado diretor.

Se o aspecto organizacional das atividades produtivas e experimentais era considerado satisfatório, o aprendizado escolar das crianças, porém, deixava a desejar. Na maior parte dos relatórios existentes, afirmava-se que os meninos eram bem tratados, moralizados e adequadamente educados, o que tornaria a instituição digna de proteção do poder público. Todavia, o juiz de órfãos encarregado de inspecionar a Colônia Blasiana apresentou um relatório desanimador sobre a situação da instituição, da educação dos meninos e do trabalho da direção.

O estado de prosperidade da Colônia, não posso senão, com a maior magoa, informar a V. Exma. que ela não tem prosperado por não satisfazer de modo algum o diretor o encargo para si tomado como era de desejar e esperar de sua inteligência, zelo e caridade. Assim a instrucção primaria não é dada aos colonos por um professor ou por pessoa competente e sim por pessoas indeterminadas e sem os precisos conhecimentos e capacidade, e não assiduamente. Não 
podendo o Director residir e permanecer constantemente na Colonia, não tem nele uma pessoa capaz de o substituir, como se obriga, ficando os colonos entregues a si nesta ocasião com grande prejuiso. ${ }^{16}$

É provável que as denúncias do juiz de órfãos sejam procedentes, uma vez que o diretor era uma pessoa assoberbada pelo acúmulo de cargos e funções que assumia. A direção da instituição era apenas um compromisso a mais, o que representava dispêndio de tempo e recursos pessoais. Manter-se no cargo de diretor, porém, só se tornava recompensador pela notoriedade que despertava entre políticos, intelectuais, pesquisadores, viajantes e missionários. Cabe lembrar que, em Goiás, a experiência da educação agrícola para crianças pobres era inovadora, granjeando, portanto, a curiosidade e a admiração das pessoas influentes da época.

A Colônia Blasiana encerrou suas atividades no ano de 1895, sob a justificativa de contenção de gastos públicos. Essa experiência não chegou a se propagar para outros municípios goianos, embora a intenção inicial fosse a de difundi-la para outros recantos da Província. Em termos de repercussão na resolução da problemática da criança escrava ou abandonada, o desempenho da Colônia Blasiana foi medíocre, se se considerar que nela foram educadas apenas 43 crianças, em um universo de milhares delas vivendo na miséria pelas cidades, vilas e campos de Goiás.

\section{UMA FORMAÇÃO PROFISSIONAL PARA A SUBSERVIÊNCIA}

Aos olhos dos dirigentes políticos, o mínimo que se fazia para as crianças abandonadas era considerado bastante. O máximo que se proporcionava era uma educação que preparava para o trabalho manual e subalterno. A Colônia formava os meninos para que fossem bons trabalhadores agrícolas e tivessem o domínio de algumas técnicas e procedimentos considerados modernos para a época. Quando atingiam 21 anos de idade, os colonos emancipavam-se e, ao saírem da instituição, incorporavam-se como trabalhadores braçais nas fazendas adjacentes. Em 1889, por ocasião da emancipação de dois alunos, o diretor frisou as qualidades e as perspectivas de vida dos rapazes:

Ambos são homens morigerados, bons lavradores práticos, e portanto aptos para se constituírem intermediarios da grande lavoura: um já se 
casou e o outro vai se casar. Os colonos emancipados irão se collocando nas immediações do estabelecimento que lhes melhorou a sorte e deu-lhes um peculio para o início da vida que vão tomar. ${ }^{17}$

Dessa forma, os meninos eram educados no e para o trabalho manual. Reservava-se-lhes um espaço subalterno na divisão social, com a incorporação em serviços braçais nas fazendas particulares, tão logo se emancipassem. Na lógica dos dirigentes da época, às crianças pobres cabia apenas uma preparação para o trabalho manual, para que melhor servissem aos proprietários das terras. Tratava-se, antes de tudo, de salvaguardar a agricultura de um possível colapso que se configurava no processo de mudanças nas relações sociais de trabalho, com a abolição da escravatura. Nisso tudo, restava às crianças negras, pobres e abandonadas o trabalho precoce e uma vida totalmente dedicada a um contínuo servilismo, em troca de comida, algumas roupas e um abrigo. Reproduziase, assim, uma exclusão histórica, econômica e ideológica - que se mantém até hoje -, em que os pobres devem ser educados prematuramente para os trabalhos manuais e de baixo prestígio social.

A visão desqualificadora do trabalho manual não era uma novidade na sociedade brasileira. Desde a escravidão, a noção de trabalho, especialmente o manual, estava impregnada de forte carga depreciativa. Não se pode negar que os condicionantes econômicos exigiram dos senhores o trabalho de administração e supervisão das unidades produtivas e, por vezes, também o trabalho de execução. Porém, a prática regular do trabalho dos senhores e dos escravos diferenciava-se consideravelmente. Os empreendimentos econômicos eram estabelecidos e controlados pelos senhores, que buscavam a riqueza através da exploração da mão-de-obra dos escravos. Mesmo que poucos pudessem se desobrigar do trabalho, reinava uma ideologia, elaborada pela sociedade escravista, que concebia o trabalho manual como referência à degradação, daí ser algo próprio para os escravos. Essa ideologia, ao mesmo tempo, conferia uma posição social privilegiada aos senhores que podiam livrar-se do peso do trabalho. Como destacou Franco (1997, p. 213), o trabalho não aparecia como elemento necessariamente desqualificador, mas como elemento de diferenciação social e de poder: "trata-se de uma sociedade escravocrata, em que forçosamente o princípio da separação nítida entre o requisito do trabalho e o privilégio de sua dispensa se fazia fundamental para a própria afirmação do poder". 
A visão depreciativa do trabalho feito com as mãos e a diferenciação socioeconômica da sociedade escravista encontravam fundamentos nos dispositivos legais vigentes na época. De acordo com Ianni (1978), a sustentação do escravismo tinha inspiração no Direito Romano que "coisificava" o escravo, classificando-o como "peça", "coisa" ou "mercadoria". Nessa condição, o escravo podia ser submetido às relações decorrentes de propriedade, tais como: compra, venda, troca, aluguel, empréstimo, hipoteca, herança, entre outras. Ademais, o escravo era duplamente alienado: em primeiro lugar, na sua pessoa, porque era mercadoria de propriedade de seu senhor; em segundo lugar, na sua força de trabalho, uma vez que não tinha poder de comandá-la. Sem a faculdade de negociar a si mesmo e nem mesmo sua força de trabalho, o escravo era forçado a produzir muito além do que recebia para viver e reproduzir-se, para retornar e ampliar os investimentos realizados pelo seu senhor. Garantiam-se, dessa forma, o monopólio de bens econômicos e, por consequiência, a estabilidade da organização social escravista.

A redução do escravo à condição de mera "coisa", combinada à noção depreciativa do trabalho manual, impediu o desenvolvimento de um sistema de educação formal destinado à qualificação dos segmentos sociais compostos de escravos, bem como de homens livres e pobres. A mão-de-obra utilizada nas atividades agropecuárias, mineradoras, extrativistas, artesanais, domésticas, entre outras, parecia não exigir qualificação profissional mais específica e nem mesmo o domínio da leitura e da escrita. $\mathrm{O}$ regime de escravidão, associado às condições econômicas, técnicas e sociais do conjunto da sociedade, não foi propício ao desenvolvimento de sistema de ensino. Por outro lado, as condições políticas vigentes no período colonial impediram o desenvolvimento de um sistema educacional, em face da possibilidade de surgimento das indesejáveis revoltas e lutas pela libertação política. Com a independência do Brasil, passou a haver uma maior preocupação com o desenvolvimento de um sistema educacional, mas, mesmo assim, mantinha-se a negligência com a educação dos segmentos sociais marginalizados (PAIVA, 1987, p. 58; Freitag, 1986, p. 47).

$\mathrm{Na}$ medida em que o capitalismo atingiu um certo grau de desenvolvimento em escala internacional tornou-se difícil a reprodução das relações escravistas de produção, o que resultou na criação progressiva de condições econômicas, políticas e sociais para a expansão do trabalho livre no Brasil. Diante das transformações estruturais então em 
curso, as classes dominantes trataram de promulgar a Lei de Terras, em 1850, para restringir o acesso da terra apenas aos homens ricos e influentes, bem como para reproduzir a dependência pessoal dos escravos libertos, homens pobres e imigrantes estrangeiros. A criação desse instrumento jurídico unificou o poder do Estado com os interesses dos grandes fazendeiros, para impedir que os trabalhadores sem recursos tivessem acesso à terra. Ou seja, o monopólio da terra criou uma nova forma de cativeiro capaz de sujeitar os indivíduos que não dispunham desse importante meio de produção. A apropriação de grandes extensões de terra tornava-se a condição necessária para dispor de mão-de-obra em abundância, a fim de substituir o trabalho escravo (MARTINS, 1973; 1986).

Dessa forma, a dominação pessoal que os homens livres e pobres sofriam durante a escravidão, analisada com maestria por Maria Sylvia de Carvalho Franco (1997), permaneceu como uma espécie de código moral que permeava as relações sociais entre fazendeiros e trabalhadores. A concentração da propriedade fundiária tornou-se o novo instrumento que garantiu a continuidade e a reprodução dos vínculos de dependência pessoal. Os homens formalmente livres, independentemente da cor da pele, tornaram-se "dependentes" ou "agregados" das grandes fazendas. Esses agregados podiam assumir funções de vaqueiro, tropeiro, sitiante, doméstica ou, até mesmo, de homem de confiança e de força armada do patrão. O elemento unificador de todas essas diferentes funções era o vínculo de dependência pessoal que aparecia com um acordo voluntário entre agregados e patrões. Por isso, se os proprietários concediam proteção e direito de uso da terra, os agregados deveriam retribuir com trabalho, favor e lealdade.

No caso específico de Goiás, foi promulgada, em 1892, a Lei de Locação de Serviços, que conferiu as bases legais para a reprodução dos vínculos de dependência pessoal, através de um sistema de endividamento dos trabalhadores. Surgia daí a escravidão por dívida. Essa lei não foi organizada em termos de valores universalistas ou impessoais, o que impossibilitava o exercício dos direitos contratuais na normatização das relações sociais. Na ausência de direitos dotados de objetividade, as relações sociais continuaram se estruturando no exercício das vontades privadas, conferindo poderes aos patrões para impor a lógica da lealdade e da subserviência sobre o coletivo de homens pobres. Através do aparato legal e institucional, o Estado foi reproduzindo as visões incrustadas nas 
práticas cotidianas que determinavam valores e espaços marginais a todos os indivíduos e grupos sociais pobres, tanto na vida econômica quanto na política.

Como analisou Souza (2003), as transformações nas relações de produção naturalizaram as desigualdades na sociedade brasileira, engendrando, com isso, processos históricos de construção social da subcidadania. As velhas concepções e práticas sociais fundamentadas na dependência pessoal e na contraprestação de favor-proteção foram sedimentando-se na sociedade, mantendo amplos segmentos sociais despreparados para assumir novas condições socioeconômicas. A herança escravocrata naturalizou a existência e a percepção de "subgente", submeteu os homens pobres e trabalhadores à condição de marginalidade, formando

uma "ralé" de inadaptados às demandas da vida produtiva e social modernas, constituindo-se numa legião de 'imprestáveis', no sentido sóbrio e objetivo deste termo, com óbvias consequiências, tanto existenciais, na condenação de dezenas de milhões a uma vida trágica sob o ponto de vista material e espiritual, quanto sociopolítica e econômica desses setores. (SouZA, 2003, p. 184)

A Colônia Blasiana - na qualidade de instituição estatal dirigida para o ensino profissionalizante - também reproduziu essa visão da "subcidadania" e validou um projeto pedagógico revestido de práticas sociais assistencialistas, autoritárias e moralistas. Além disso, as práticas pedagógicas eram preconceituosas e discriminatórias porque se destinavam às crianças negras, pobres e abandonadas, limitando-se apenas em "salvá-las" da marginalidade para depois integrá-las nos serviços braçais, requisitados pelas grandes propriedades agrícolas. A Colônia Blasiana não educou os seus alunos para a afirmação da cidadania, com vistas à emancipação social; ao contrário, educou-os para serem trabalhadores dóceis, subservientes e condenados a uma vida marginal nas dimensões existencial, econômica e política.

\section{ABSTRACT}

At the end of the $19^{\text {th }}$ century, the government of the Province of Goiás founded the first professional occupation institution, directed especially towards poor, black and abandoned children. The Blasiana Colônia was conceived to train 
agricultural workers, based on the educational principles of work and discipline. However, a subordinate role in the social division of labor was reserved for them, because as soon as they left, the only job options available to them were those of manual laborers on privately-owned farms.

Key words: professional education, childhood, agricultural teaching, Goiás.

\section{NOTAS}

1. Relatório lido na abertura da Assembléia Legislativa de Goiás pelo Exmo. Sr. José Martins Pereira Alencastre, no dia $1^{\circ}$ de junho de 1862. Cf. Memórias goianas, v. 9. Goiânia: Editora da UCG, 1998. p. 108.

2. Relatório que o Exmo. desembargador João Bonifácio Gomes Cerqueira, vicepresidente da Província de Goiás, leu na abertura da Assembléia Legislativa da mesma Província, no dia $1^{\circ}$ de setembro de 1868 . Cf. Memórias goianas, v. 10. Goiânia: Editora da UCG, 1998.p. 218.

3. Relatório apresentado à Assembléia Legislativa de Goiás, na sessão ordinária de 1858, pelo Exmo. presidente da Província Dr. Francisco Januário da Gama Cerqueira. Cf. Memórias goianas, v. 7. Goiânia: Editora da UCG, 1997. p. 192.

4. Relatório apresentado a Assembléia Legislativa Provincial de Goiás pelo Exmo. Sr. Dr. Antero Cícero de Assis, em $1^{\circ}$ de junho de 1875. Cf. Memórias Goianas, v.12. Goiânia: Editora da UCG, 1999. p. 53.

5. Cf. Meireles, J. D. Apresentação. In: Alvares, J. M. Descrição histórica, política e geográfica de Santa Luzia. Brasília: Editora Gráfica Independente, 1978.

6. Relatório da Colônia Blasiana, redigido por Joseph de Mello Alvares, datado de 15 de janeiro 1889. Arquivo Histórico Estadual - Goiás. Documentação Avulsa. Caixa arquivo n. 391. Ano 1889.

7. A proposta de intervenção do Estado para educar crianças em instituições públicas foi motivo de conflito de interesses. No ano de 1884, a Colônia Blasiana sofreu uma ameaça de invasão por um grupo de pessoas armadas, liderado por fazendeiros que queriam retomar dois filhos de escravas que estavam internados no estabelecimento por determinação do juiz de órfãos. $\mathrm{O}$ diretor resistiu ao ataque, solicitando apoio policial para garantir a integridade física das crianças e funcionários. Esse episódio demonstra que os interesses dos fazendeiros não estavam de acordo com os propósitos do Estado de tomar a soldada as crianças filhas de escravas para educá-las naquelas instituições públicas que começavam a surgir no período. Indica também que os fazendeiros desejavam reter as crianças em suas propriedades para dispor da força de trabalho e que, na perspectiva deles, a resolução do 
problema da infância desvalida estava no âmbito das esferas privadas, como historicamente vinha ocorrendo.

8. Relatório da Colônia Blasiana, redigido por Joseph de Mello Alvares, datado de 15 de janeiro de 1889.

9. Regulamento da Colonia Blasiana. Correio Official, n. 42, Goiás, ano XLIV, 4 jun. 1882.

10. Relatório da Colônia Blasiana, redigido por Joseph de Mello Alvares, datado de 15 de janeiro de 1889.

11. Relatório do juiz Braz Bernardino Loureiro Tavares dirigido ao vice-presidente da Província de Goiás, datado de 10 de março de 1883. Arquivo Histórico Estadual - Goiás. Documentação Avulsa. Caixa Arquivo 326. Ano 1883.

12. Relatório do Termo de Visita do Coletor de Rendas Provinciais, Sr. Moysés de Souza e Silva. Arquivo Histórico Estadual - Goiás. Documentação Avulsa. Caixa Arquivo 326. Ano 1883.

13. Relatório da Colônia Blasiana, redigido por Joseph de Mello Alvares, datado de 15 de janeiro de 1889.

14. Ata de instalação da Colônia Orfanológica. Correio Official, Goiás, n. 37, ano XLIV, 18 maio 1881.

15. Relatório da Colônia Blasiana, redigido por Joseph de Mello Alvares, datado de 15 de março de 1884. Arquivo Histórico Estadual - Goiás. Caixa Arquivo de Luziânia 42.

16. Relatório do juiz Braz Bernadino Tavares, dirigido ao vice-presidente da Província de Goiás, datado de 10 de março 1883.

17. Relatório da Colônia Blasiana redigido por Joseph de Mello Alvares, datado de 15 de janeiro de 1889.

\section{REFERÊNCIAS}

ALVARES, J. M. Descrição histórica, política e geográfica de Santa Luzia. Brasília: Independente, 1978.

BRETAS, G. F. História da instrução pública em Goiás. Goiânia: Editora da UFG, 1991.

COIMBRA, C. M. B.; NASCIMENTO, M. L. Jovens pobres: o mito da periculosidade. In: FRAGA, P. C. P.; IULIANELLI, J. A. (Orgs.). Jovens em tempo real. Rio de Janeiro: DP\&A, 2003.

FALEIROS, E. T. S. A criança e o adolescente: objetos sem valor no Brasil Colônia e no Império. In: PILOTTII, F.; RIZZINI, I. (Orgs.). A arte de governar 
crianças: a história das políticas sociais, da legislação e da assistência à infância no Brasil. Rio de Janeiro: Inst. Interamericano del Niño: Ed. Univ. Santa Úrsula: Amais, 1995.

FALEIROS, V. P. Infância e processo político no Brasil. In: PILOTTI, F.; RIZZINI, I. (Orgs.). A arte de governar crianças: a história das políticas sociais, da legislação e da assistência à infância no Brasil. Rio de Janeiro: Inst. Interamericano del Niño: Ed. Univ. Santa Úrsula: Amais, 1995.

FOUCAULT, M. Microfísica do poder. Rio de Janeiro: Graal, 1979.

FOUCAULT, M. Vigiar e punir. História da violência nas prisões. Petrópolis: Vozes, 1986.

FRANCO, M. S. C. Homens livres na ordem escravocrata. São Paulo: Editora da Unesp, 1997.

FREITAG, B. Escola, estado e sociedade. São Paulo: Moraes, 1986.

IANNI, O. Escravidão e racismo. São Paulo: Hucitec, 1978.

LEAL, O. Viagem às terras goyanas (Brasil Central). Goiânia: Editora da UFG, 1980.

MARIN, J. O. B. Entre a abolição e a escravatura: estudo das leis de emancipação e de locação de serviços em Goiás. II CICLO DE ESTUDOS DO INSTITUTO DE PESQUISAS E ESTUDOS HISTÓRICOS DO BRASIL CENTRAL. Anais.... Goiânia: UCG, 2004. [CD-ROM]

MARIN, J. O. B. Crianças do trabalho. Goiânia: Editora da UFG; Brasília: Plano, 2005.

MARTINS, J. S. A imigração e a crise do Brasil agrário. São Paulo: Pioneira, 1973.

MARTINS, J. S. O cativeiro da terra. São Paulo: Hucitec, 1986.

PAIVA, V. P. Educação popular e educação de adultos. São Paulo: Loyola, 1987.

RIZZINI, I. Crianças e menores: do pátrio poder ao pátrio dever: um histórico da legislação para a infância no Brasil. In: PILOTTI, F., RIZZINI, I. (Orgs.). A arte de governar crianças: a história das políticas sociais, da legislação e da assistência à infância no Brasil. Rio de Janeiro: Inst. Intramericano del Niño: Ed. da Univ. Santa Úrsula: Amais, 1995.

ROCHA, L. M. O Estado e os índios: Goiás, 1850-1889. Goiânia: Editora da UFG, 1998.

SANTOS, E. A. Os dominicanos em Goiás e Tocantins (1881-1930): fundação e consolidação da missão. Goiânia, 1996. Dissertação (Mestrado em História) Universidade Federal de Goiás. 
SOUZA, J. A construção social da subcidadania: para uma sociologia política da modernidade periférica. Belo Horizonte: Editora da UFMG; Rio de Janeiro: IUPERJ, 2003.

VEIGA, J. E. O desenvolvimento agrícola: uma visão histórica. São Paulo: Editora da USP/Hucitec, 1991. 
